CLINICAL STUDY

\title{
Moderate energy restriction-induced weight loss affects circulating IGF levels independent of dietary composition
}

\author{
Damien P Belobrajdic, Jan Frystyk ${ }^{1}$, Nilani Jeyaratnaganthan ${ }^{1}$, Ulrick Espelund ${ }^{1}$, Allan Flyvbjerg ${ }^{1}$, \\ Peter M Clifton and Manny Noakes \\ Commonwealth Scientific Industrial Research Organisation (CSIRO), Food and Nutritional Sciences, PO Box 10041, Adelaide BC, South Australia \\ 5000, Australia and ${ }^{1}$ The Medical Research Laboratories, Clinical Institute of Medicine and Department of Endocrinology and Internal Medicine, \\ Aarhus University Hospital, DK-8000 Aarhus C, Denmark \\ (Correspondence should be addressed to D P Belobrajdic; Email: damien.belobrajdic@csiro.au)
}

\begin{abstract}
Background: Obesity is associated with major changes in the circulating IGF system. However, it is not clear to what extent the IGF system is normalized following diet, and the possible role of different types of diet is also unknown.

Objective: To compare changes in the circulating IGF system following 12 weeks of moderate energy restriction $(7000 \mathrm{~kJ} /$ day) in overweight or obese males on a high protein high red meat diet (HP) or a high carbohydrate diet (HC).

Design: Seventy-six men (mean age, $51 \pm 1.0$ years; body mass index, $32.8 \pm 0.5 \mathrm{~kg} / \mathrm{m}^{2}$ ) were allocated to matched groups treated with isocaloric diets of HP $(n=34)$ or HC $(n=42)$. Outcome measures were weight, body composition, IGF-related peptides, homoeostasis model assessment of insulin resistance (HOMA1-IR) and adipokines.

Results: Weight loss did not differ between diets (HP $8.5 \pm 0.6 \mathrm{~kg}$; HC $8.2 \pm 0.6 \mathrm{~kg}, P>0.05$ ). IGF-related peptides increased total IGF1 (HP 23\%; HC 18\%, P<0.0001), bioactive IGF1 (HP 18\%; HC $15 \%, P<0.002$ ), IGF1:IGF-binding protein-3 (IGFBP-3; HP 29\%; HC 22\%, P<0.0001) and IGFBP-1 (HP 24\%; HC 25\%, P<0.01). By contrast, decreases were observed in IGFBP-3 (HP $-4 \%$; HC $-3 \%$, $P<0.01$ ), pro-IGF2 (HP $-3 \%$; HC $-6 \%, P=0.001$ ), total IGF2 (HP $-7 \%$; HC $-3 \%, P=0.001$ ) and sIGF2R (HP $-10 \%$; HC $-6 \%, P<0.005)$. Only IGFBP-2 increased differentially by diet (HP $34 \%$; HC 50\%, $P<0.0001$, diet $P<0.05)$. Adiponectin increased in both diets, but leptin and HOMA-IR decreased $(P<0.001)$.

Conclusions: Weight loss induced by moderate energy restriction modulated the IGF system independent of dietary protein or red meat content. The effect of diet on IGFBP-2 appeared to have limited biological effect as total IGF2 and pro-IGF2 did not change.
\end{abstract}

European Journal of Endocrinology 162 1075-1082

\section{Introduction}

Weight loss through energy restriction has a significant impact on improving cardiovascular disease (CVD) risk profile including favourable changes in adipokines (adiponectin and leptin), hyperlipidaemia, hypertension and insulin sensitivity $(1,2)$. Weight loss also affects the insulin-like growth factor (IGF) system which can modulate carcinogenesis, CVD progression and longevity $(3,4)$.

Obesity is associated with major changes in the circulating IGF system. Most characteristically is a markedly reduced GH secretion, which, however in some studies, appears to be sufficient to maintain circulating levels of immunoreactive, free as well as bioactive IGF1 within the normal to high range (5), whereas other studies have reported that free IGF1 in obesity is in the lower normal range (6-8) or decreased $(9,10)$. Furthermore, obesity is associated with elevated IGF2 levels and reduced levels of the two insulinsuppressible IGF-binding proteins (IGFBPs), IGFBP-1 and $-2(5,11)$.

In obese subjects, the response of the IGF system to fasting or moderate energy restriction differs from healthy non-obese subjects. Short-term fasting (4 days) decreased total IGF1 to a greater extent in non-obese than obese subjects, whereas IGFBP-1 increased, and IGFBP-3 was unchanged for non-obese and obese subjects (12). However, when obese subjects followed a very low calorie diet $(800 \mathrm{kcal} /$ day $)$ for 8 weeks, total IGF1 and IGFBP-1 and -2 increased, free IGF1 remained stable, and total and free IGF2 decreased (13). How these changes may affect IGF bioactivity remains unknown. 
In addition to the energy content of a diet, dietary composition may also be associated with circulating IGF levels in obesity. A 3-month dietary intervention combined with exercise showed that a high protein (HP) diet ( $40 \% \mathrm{En})$ in comparison to a moderate protein diet $(25 \%$ En) significantly increased total IGF1 and IGFBP-1 (14). However, the diets were not matched for energy intake, and therefore a study that controls for energy intake is required to identify whether an HP diet per se can increase IGF1 and IGFBP-1. To date, the effect of diet composition on IGF1 bioavailability has not been reported in an intervention study.

We aimed to investigate the effect of weight loss in subjects on an HP high red meat diet compared to a low red meat high carbohydrate (HC) diet in obese men on IGF1 bioavailability as determined by a cellbased assay, which measures the ability of serum to activate the IGF1 receptor (IGF1R) in vitro, and accordingly integrates the signals from IGF1, IGF2 and the IGFBPs. In addition, we compared IGF1 bioactivity to immunoreactive levels of IGF1, IGF2, pro-IGF2, the IGFBPs and the soluble IGF2 receptor (sIGF2R). Changes in body weight (BW), abdominal fat mass, insulin sensitivity and adipokine levels (adiponectin and leptin) following weight loss were used to confirm that the diets were sufficient to induce physiological alterations.

\section{Subjects and methods}

\section{Subjects}

Overweight and obese men with abdominal obesity and at least one other additional risk factor for the metabolic syndrome according to the criteria of the International Diabetes Federation were recruited by public advertisement to participate in a 12-week outpatient weight loss trial (15). Subjects were excluded if they had a history of liver, cardiovascular, peripheral vascular, respiratory or gastrointestinal disease, diabetes or malignancy. Prior to the study, participants completed a health and physical activity screening questionnaire, and were not eligible to participate if they were currently consuming a weight loss diet or if their weight had fluctuated by more than $3 \mathrm{~kg}$ in the 6 months prior to the study or had widely fluctuating exercise patterns. Accordingly, all included subjects were considered weight stable at the time of study commencement. One hundred and twenty-three subjects aged $51 \pm 1$ years with a body mass index (BMI) of $32.8 \pm 0.5 \mathrm{~kg} / \mathrm{m}^{2}$ were enrolled in the study.

The study protocol was approved by the Human Ethics Committee of the Commonwealth Scientific Industrial Research Organization (CSIRO), and the subjects provided written informed consent.

\section{Study design}

In a parallel design, participants were matched for age and BMI, and were randomly assigned to isocaloric energy-restricted diets either HP $(n=61)$ or HC $(n=62)$ for 12 weeks. At baseline (week 0 ) and after weight loss (week 12), participants attended the clinical research unit at CSIRO after an overnight fast. At each visit, height, weight and blood pressure of the participants were measured. Body composition was determined using dual-energy X-ray absorptiometry, and a venous blood sample was collected and the serum was stored at $-80^{\circ} \mathrm{C}$. A subset of serum samples (HP, $n=34$; HC, $n=42$ ) were available for IGF analyses. A range of other experimental end points were also measured, and these have been reported previously (16-18). Throughout the intervention, participants attended the clinic fortnightly for a weight check and a consultation with a dietitian. Apart from the dietary intervention, subjects were asked to maintain their usual lifestyle throughout the study.

\section{Dietary intervention}

Subjects attended individual consultations with a dietitian who prescribed the appropriate protein and kilojoule $(\mathrm{kJ})$ level for the individual, and provided instruction on the structured eating plan and dietary requirements, method for recording food intake and need for compliance.

Subjects were issued with digital kitchen scales to weigh food. They were encouraged to consume two cups or more of low carbohydrate vegetables per day, and a range of additional low energy foods were allowed. Four standard serves of alcohol were permitted per week. Each 2 weeks until 12 weeks, subjects attended the Clinical Research Unit and were supplied with key food items (red meat or chicken, breakfast cereal, bread and dairy foods) that were consistent with their allocated diet to encourage compliance. Each supply provided $\sim 60 \%$ of projected daily total energy intake and was isocaloric between groups.

The fatty acid profile of diets was planned to be the same between diets. Checklists of all foods consumed were completed daily, and 3-day weighed food records were analysed in each 2-week period.

The protein for the HP diet was based on $1.5 \mathrm{~g}$ protein per kg BW. The HC pattern was matched to the HP pattern in total $\mathrm{kJ}$ and saturated fat. The template diets for the $7000 \mathrm{~kJ}$ levels are outlined in Table 1. Higher and lower energy levels were proportional to these amounts to ensure the same protein:energy ratios.

Dietary intake was assessed from daily checklists and weighed food records kept by participants. Assessment of food intake at baseline and for a 3-day period for every 2 weeks during the 12-week intervention was performed using a food frequency questionnaire (FFQ) by the AntiCancer Council of Victoria (ACCV), which has been validated by Hodge et al. (19) and Xinying et al. (20). 
Table 1 Diet template for the $7000 \mathrm{~kJ}$ dietary interventions.

\begin{tabular}{|c|c|c|}
\hline & High protein & High carbohydrate \\
\hline Cereal & $20 \mathrm{~g}$ high fibre cereal +2 Weet-Bix & $20 \mathrm{~g}$ high fibre cereal +2 Weet-Bix \\
\hline Dairy low fat & $\begin{array}{l}\text { Three serves ( } 500 \mathrm{ml} \text { reduced fat } \\
\text { milk }+250 \mathrm{~g} \text { diet yoghurt) }\end{array}$ & $\begin{array}{l}\text { One serve }(250 \mathrm{ml} \text { reduced fat milk } \\
\text { or equivalent) }\end{array}$ \\
\hline Lean meat/poultry/fish (dinner) & $300 \mathrm{~g}$ (red meat 4 times/week) & $100 \mathrm{~g}$ (red meat $<2$ times/week) \\
\hline Lean meat/poultry/fish (lunch) & $100 \mathrm{~g}$ & $30 \mathrm{~g}$ \\
\hline Cheese full fat & - & $30 \mathrm{~g}$ \\
\hline Fresh fruit & $300 \mathrm{~g}$ & $450 \mathrm{~g}$ \\
\hline Pasta/rice (or potato equivalent) & Nil & $70 \mathrm{~g}$ dry weight \\
\hline Salad & $1 / 2$ cup & $1 / 2$ cup \\
\hline Vegetables & (at least 2.5 cups) & (at least 2.5 cups) \\
\hline Oil/spread & $20 \mathrm{~g}$ & $20 \mathrm{~g}$ \\
\hline Bread wholegrain & $105 \mathrm{~g}$ & $140 \mathrm{~g}$ \\
\hline Wine or equivalent (optional) & $750 \mathrm{ml} /$ week & $750 \mathrm{ml} /$ week \\
\hline
\end{tabular}

\section{Biochemical analyses}

All samples from each participant were analysed within the same assay run in duplicate. Plasma glucose was measured on a Hitachi 902 autoanalyzer (Roche Diagnostics) using a commercial enzymatic kit (Roche Diagnostics). Plasma insulin concentrations were determined using a commercial ELISA kit (Mercodia ELISA; ALPCO Diagnostics, Uppsala, Sweden). Insulin resistance was estimated using the homeostatic model assessment (HOMA) (21).

Total serum IGF1 and 2 were measured after acid ethanol extraction with non-competitive time-resolved immunofluorometric assays (TR-IFMA; PerkinElmer LifeSciences, Turku, Finland) with intra- and interassay coefficients of variance (CV) of 5 and $10 \%$ respectively (22).

Bioactive IGF1 was measured by the IGF1 kinase receptor activator assay based on human embryonic renal cells (EBNA 293) transfected with the human IGF1R gene (23). In brief, cultured cells were stimulated with either IGF1 standards or serum samples (diluted tenfold) from the subjects in this study. After $15 \mathrm{~min}$, samples were removed, and the cells were lysed. The crude cell lysates were then transferred to an assay that detects the concentration of phosphorylated (e.g. activated) IGF1Rs. This assay uses a monoclonal capture antibody against the extracellular IGF1R and a europium-labelled monoclonal antiphosphotyrosine antibody (PY20) as the tracer. The assay is sensitive (detection limit $<0.08 \mu \mathrm{g} / \mathrm{l}$ ), specific (IGF2 crossreactivity is $12 \%$; proinsulin, insulin and insulin analogues have a cross-reactivity $<1 \%$ ) and precise (mean with-in and in-between assay $\mathrm{CV}$ were $<7$ and $<15 \%$ ).

Serum IGFBP-1 was measured by in-house RIA performed as described by Westwood et al. (24) with modifications (25) and intra- and inter-assay CV of 5 and $12 \%$ respectively. The assay had been calibrated against a commercial IGFBP-1 ELISA (Diagnostic Systems Laboratories (DSL), Webster, TX, USA).
Serum IGFBP-2 was determined by an in-house TR-IFMA with an intra- and inter-assay CV of 5 and $12 \%$ respectively (26).

Serum IGFBP-3 was measured using a commercial RIA from DiaSource (Nivelles, Belgium). The IGF1:IGFBP-3 molar ratio was calculated based on $1 \mu \mathrm{g} / \mathrm{l} \mathrm{IGF} 1=0.130 \mathrm{nmol}$ IGF 1 and $1 \mu \mathrm{g} / \mathrm{l} \mathrm{IGFBP}-3=$ $0.036 \mathrm{nmol}$ IGFBP-3.

Pro-IGF2 was measured by in-house TR-IFMA as described in detail in Espelund et al. (13). The intra- and inter-assay $\mathrm{CV}$ were $<5$ and $<11 \%$ respectively.

sIGF2R levels were determined by a novel-validated in-house TR-IFMA as recently described (27). In brief, the assay uses a commercial polyclonal anti-human IGF2/M6P-R antibody for catching and detection, and truncated rhIGF2/M6P-R as standard (both obtained from R\&D Systems, Abingdon, UK). All in-house assays have a with-in and in-between assay $\mathrm{CV}$ averaging $<8$ and $16 \%$.

Total adiponectin was measured by TR-IFMA as described (28) with intra- and inter-assay CV of 5 and $10 \%$. Leptin was determined by a validated in-house TR-IFMA based on commercial reagents (from R\&D Systems: two MABs (catalogue numbers MAb 398 for coating and BAM 398 for detection) and recombinant human leptin as standard (catalogue number 398-LP)), and carried out essentially as the adiponectin TR-IFMA (28). The recovery of exogenously added leptin to serum averaged $96.8 \pm 0.2 \%$, the intra-assay $\mathrm{CV}$ averaged $<5 \%$ and the inter-assay $\mathrm{CV}$ averaged $<10 \%$ ( $>50$ assay set-ups).

\section{Statistical analysis}

Data are presented as means \pm s.E.M. Two-tailed statistical analysis was performed using SPSS for Windows 16.0 software (SPSS Inc., Chicago, IL, USA) with statistical significance set at $\alpha$ level of $P<0.05$. IGF data were normalized by log transformation prior to analysis. Baseline data were assessed using a Student's $t$-test. Comparisons over time and between groups were 
assessed using two-way repeated-measures ANOVA. In the presence of a significant time by treatment interaction, Tukey's post hoc tests were conducted on the simple main effects. Pearson linear regression analysis was used to estimate correlations between log-transformed IGF values and other variables measured. The Holm method was used to correct for multiple testing (29).

\section{Results}

There were no differences in baseline energy intake between subjects consuming the two diets as assessed using the ACCV FFQ (Supplementary Data, see section on supplementary data given at the end of this article). Differences in grams of protein, \% energy from protein, grams of carbohydrate and \% energy from carbohydrate were achieved (Supplementary Data). Fibre intake was also significantly different, but both diets reached adequate intake (AI). Significant differences in micronutrient intakes (calcium, iron and zinc) suggest that overall the HP diet was more nutrient dense than the HC diet (Supplementary Data).

Baseline characteristics are shown in Table 2. At baseline, there were no differences between the dietary treatment groups for any of the parameters measured. Following 12 weeks of dietary intervention, both diets had similar effects on improving body composition (Table 2). There were significant reductions $(P<0.0001)$ in $\mathrm{BW}$ on both diets at 12 weeks (HP, $9 \pm 0.6 \mathrm{~kg} ; \mathrm{HC}, 8 \pm 0.5 \mathrm{~kg}$ ) with no significant difference between diets. At 12 weeks, there was a greater reduction in abdominal fat mass on $\mathrm{HP}$ ( $\mathrm{HP}-0.76$ $\pm 0.38 \mathrm{~kg}$ versus $\mathrm{HC}-0.56 \pm 0.36 \mathrm{~kg} ; P<0.02)$. There was also a trend for body fat mass loss on HP in comparison to $\mathrm{HC}(P=0.079$ for time by diet interaction). As a result of the changes in body composition overall, there were marked improvements in fasting insulin ( $\mathrm{HP}-34 \pm 1 \%$; $\mathrm{HC}-33 \pm 4 \%$,
$P<0.0001$ ) and insulin sensitivity (HP $37 \pm 4 \%$; $\mathrm{HC}$ $35 \pm 3 \%, P<0.0001$; Table 2). Furthermore, adiponec-

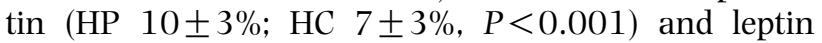
(HP $-50 \pm 4 \%$; HC $-46 \pm 2 \%, P<0.0001)$ improved following both diets (Table 2). At 0 and 12 weeks, leptin was significantly associated with BW $(r=0.533$, $P<0.001 ; \quad r=0.49, \quad P<0.001)$, total fat mass $(r=0.69, \quad P<0.001 ; r=0.64, P<0.001)$ and total abdominal fat mass $(r=0.55, P<0.001 ; r=0.58$, $P<0.001)$. Adiponectin did not correlate with these measures, but did correlate with HOMA1-IR at 12 weeks $(r=-0.45, P<0.01)$.

Twelve weeks of diet intervention increased total

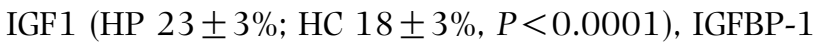
(HP $24 \pm 10 \%$; HC $25 \pm 9 \%, P<0.003)$, IGF1:IGFBP-3 (HP $29 \pm 4 \%$; HC $22 \pm 3 \%, P<0.0001$ ) and bioactive IGF1 (HP $18 \pm 6 \%$; HC $15 \pm 5 \%, P<0.002$ ), whereas IGFBP-3 decreased ( $\mathrm{HP}-3.8 \pm 1.2 \%$; $\mathrm{HC}-2.6 \pm 1.1 \%$, $P<0.0001$; Fig. 1). Bioactive IGF1 correlated with total IGF1 at baseline $(r=0.49, P<0.01)$ and at 12 weeks $(r=0.53, P<0.005)$, but did not correlate with IGFBP-1 or IGF1:IGFBP-3 (Table 3). IGFBP-1 was inversely correlated with $\mathrm{BW}$, fat mass and lean mass at baseline and at 12 weeks (Table 4 ).

Irrespective of diet type, total IGF2 decreased (HP $7 \pm 3 \% ; \quad$ HC $3 \pm 2 \%, \quad P<0.001)$, while IGFBP-2

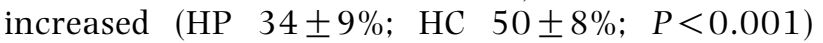
following the 12-week dietary intervention (Table 2). The change in total IGF2 over the 12 weeks was positively correlated with the changes in HOMA1-IR $(r=0.41, P<0.0001$; Table 4$)$. At week 12, IGFBP-2 was inversely correlated with BW, fat mass and lean mass (Table 4). Additionally, the $\mathrm{HC}$ diet increased

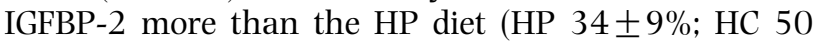
$\pm 8 \%, \mathrm{P}<0.05)$. Levels of sIGF2R ( $\mathrm{HP}-10 \pm 2 \%$; HC $-6 \pm 3 \%, P<0.0001)$ and pro-IGF2 (HP $-3 \pm 2 \%$; HC $-6 \pm 3 \%, P<0.001)$ were reduced following the HP and $\mathrm{HC}$ diets (Fig. 1). The reductions in sIGF2R and pro-IGF2 were correlated with total IGF2 most strongly at baseline $(r=0.49, P<0.0001$ and $r=0.50$,

Table 2 Body composition, insulin sensitivity and adipokines. Data are presented as mean \pm S.E.M.

\begin{tabular}{|c|c|c|c|c|c|c|c|c|}
\hline & \multicolumn{3}{|c|}{ High protein $(n=34)$} & \multicolumn{3}{|c|}{ High carbohydrate $(n=42)$} & \multirow[b]{2}{*}{ Time } & \multirow[b]{2}{*}{ Time $\times$ die } \\
\hline & Baseline $^{a}$ & Week 12 & Change (\%) & Baseline & Week 12 & Change (\%) & & \\
\hline Body weight (kg) & $103 \pm 2.5$ & $95 \pm 2.3$ & $-9 \pm 0.6$ & $101 \pm 2.2$ & $92 \pm 2.0$ & $-8 \pm 0.5$ & 0.0001 & 0.753 \\
\hline Lean mass $(\mathrm{kg})$ & $65.3 \pm 1.5$ & $63.4 \pm 1.1$ & $-3 \pm 1$ & $64.8 \pm 1.3$ & $61.7 \pm 1.0$ & $-4 \pm 1$ & 0.0001 & 0.172 \\
\hline Fat mass $(\mathrm{kg})$ & $34.3 \pm 1.4$ & $27.8 \pm 1.6$ & $-20 \pm 2$ & $32.1 \pm 1.2$ & $27 \pm 1.4$ & $-17 \pm 2$ & 0.0001 & 0.093 \\
\hline Body fat $(\%)$ & $34 \pm 0.7$ & $29.8 \pm 1.1$ & $-13 \pm 2$ & $33 \pm 0.7$ & $30 \pm 1.0$ & $-10 \pm 2$ & 0.0001 & 0.131 \\
\hline $\begin{array}{l}\text { Total abdominal } \\
\text { fat mass }(\mathrm{kg})\end{array}$ & $3 \pm 0.2$ & $2.3 \pm 0.2$ & $-25 \pm 2$ & $2.8 \pm 0.1$ & $2.3 \pm 0.1$ & $-21 \pm 2$ & 0.001 & 0.079 \\
\hline $\operatorname{BMI}\left(\mathrm{kg} / \mathrm{m}^{2}\right)$ & $33.2 \pm 0.7$ & $30.4 \pm 0.6$ & $-9 \pm 0.6$ & $31.8 \pm 0.6$ & $29.1 \pm 0.6$ & $-8 \pm 0.6$ & 0.0001 & 0.631 \\
\hline Glucose $(\mathrm{mmol} / \mathrm{l})^{\mathrm{b}}$ & $5.9 \pm 0.2$ & $5.6 \pm 0.1$ & $-5 \pm 1$ & $5.9 \pm 0.1$ & $5.6 \pm 0.1$ & $-4 \pm 2$ & 0.0001 & 0.982 \\
\hline HOMA1-IR & $3.6 \pm 0.4$ & $1.9 \pm 0.2$ & $-37 \pm 4$ & $2.8 \pm 0.4$ & $1.5 \pm 0.1$ & $-35 \pm 3$ & 0.0001 & 0.345 \\
\hline Adiponectin (mg/l) & $4.9 \pm 0.4$ & $5.3 \pm 0.4$ & $10 \pm 3$ & $5.7 \pm 0.4$ & $6.1 \pm 0.4$ & $7 \pm 3$ & 0.001 & 0.973 \\
\hline Leptin $(\mu \mathrm{g} / \mathrm{l})$ & $20 \pm 2.2$ & $10.8 \pm 1.6$ & $-50 \pm 4$ & $15.3 \pm 1.9$ & $8.7 \pm 1.4$ & $-46 \pm 2$ & 0.0001 & 0.122 \\
\hline
\end{tabular}

$\mathrm{BMI}$, body mass index (weight in $\mathrm{kg} /$ height in $\mathrm{m}^{2}$ ); HOMA1-IR, homoeostasis model assessment of insulin resistance.

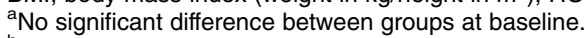

${ }^{\mathrm{b}}$ For conversion from $\mathrm{mmol} / \mathrm{l}$ to $\mathrm{mg} / \mathrm{dl}$ for glucose, multiply by 18 . 


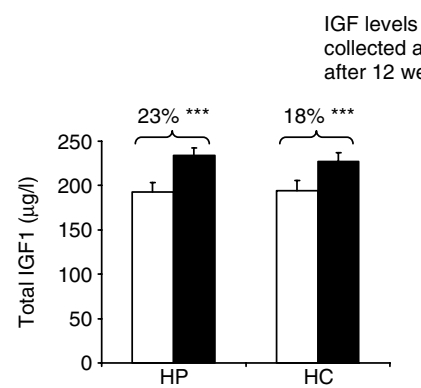

GF levels measured in samples collected at baseline $(\square)$ and after 12 weeks $(\boldsymbol{\square})$
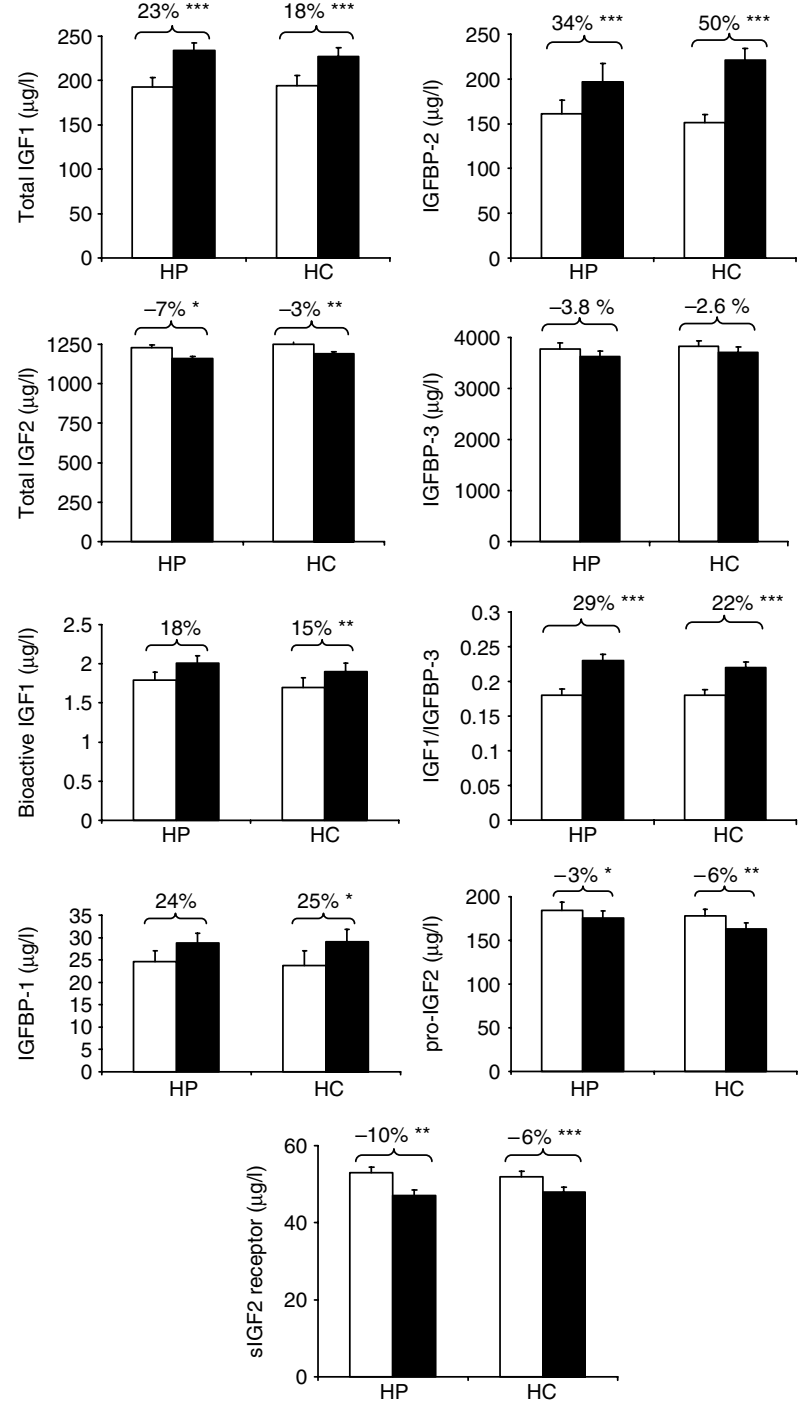

Figure 1 The effect of a 12-week energy restriction high protein (HP; $n=34)$ and high carbohydrate (HC; $n=42)$ diet on serum IGF Data shown represent mean \pm S.E.M. Significant difference between baseline and 12 weeks is denoted by ${ }^{\star} P<0.01$ and ${ }^{\star \star} P<0.001$. Diet type did not significantly affect any of the IGF variables measured, with the exception of IGFBP-2 $(P<0.05)$.

$P<0.0001$; Table 3). Furthermore, the changes in sIGF2R and pro-IGF2 were correlated with the change in total IGF2 (Table 3). The change in insulin resistance (HOMA-IR) was correlated with total IGF2 and sIGF2R (Table 4).

\section{Discussion}

This is the first clinical intervention in obese subjects to show that in the context of moderate energy restriction, the dietary composition did not affect circulating IGF levels, and with the exception of IGFBP-2, the same was true for the IGFBPs. Previously, a 3-month dietary intervention that did not control for energy intake showed that a HP diet ( $40 \%$ En) in comparison to a moderate protein diet $(25 \%$ En) significantly reduced energy intake and increased total IGF1 and IGFBP-1 (14). Taken together, this suggests that energy restriction rather than the amount of protein in the diet has the greater effect on IGF levels. In contrast, in crosssectional studies in healthy weight individuals, total IGF1 was associated with total protein (30-33) and red meat $(31,34)$. Furthermore, Fontana et al. (35) showed that reducing protein intake from an average of $1.67-0.95 \mathrm{~g} / \mathrm{kg}$ of $\mathrm{BW}$ per day for 3 weeks in six healthy weight volunteers practicing caloric restriction resulted in a reduction in serum IGF1 from 194 to $152 \mu \mathrm{g} / \mathrm{l}$. However, in the current study of obese subjects, the HP diet with moderate energy restriction did not affect total IGF1 levels any differently to the HC diet. Furthermore, the other IGF-related proteins that were measured were not affected differentially by diet type, except for IGFBP-2, which increased to a greater extent on the HC diet in comparison to the HP diet. As diet type did not affect total IGF2, pro-IGF2 or sIGF2R levels, this suggests that in the context of moderate energy restriction, the effect of diet type on IGFBP-2 levels may have limited biological significance.

Total IGF1 and IGFBP-1 increased following both diets, which is consistent with an energy restriction study in obese subjects that showed an increase in both proteins (13). Previous studies in obese subjects have reported no change in total IGF1 after short-term dietary restriction $(36,37)$. Thus, the observed changes in the current study are more likely to be due to the weight loss after a 12-week energy restriction than energy per se. In addition, in the current study, IGFBP-3 decreased and the IGF1:IGFBP-3 molar ratio and bioactive IGF1 increased following both diets. These changes in IGF1 may be regulated in part by an improvement in insulin sensitivity. We have shown that insulin resistance, as measured by HOMA1-IR, was inversely correlated with IGFBP-1 and -2 at 12 weeks. Furthermore, the change in insulin resistance following weight loss was also inversely correlated with the change in IGF1, but not bioactive IGF1. This suggests that the improvement in insulin sensitivity following weight loss may upregulate the expression of IGF1 and IGFBP-1 and -2. Insulin has been shown to directly regulate IGF1 expression in rat hepatocytes (38). Furthermore, subjects with type 1 diabetes have lower free and total IGF 1 levels than controls, and those type 1 diabetes subjects with detectable levels of C-peptide had higher levels of total and free IGF1 than subjects with undetectable levels of C-peptide (39). The increase in IGF1 and bioactive IGF1 may also be regulated by changes in GH levels following weight loss. Rasmussen et al. (40) showed that in obese subjects, weight loss restored 24-h GH release profiles to levels seen in lean 
Table 3 Correlations between insulin-like growth factor (IGF) hormones (only significant correlations have been included).

\begin{tabular}{|c|c|c|c|c|c|c|c|}
\hline & & \multicolumn{2}{|c|}{ Baseline } & \multicolumn{2}{|c|}{12 weeks } & \multicolumn{2}{|c|}{$\Delta^{\mathrm{a}}$} \\
\hline & & $r$ & $P$ value & $r$ & $P$ value & $r$ & $P$ value \\
\hline IGFBP-1 & IGFBP-2 & & & 0.603 & 0.006 & & \\
\hline IGFBP-2 & Total IGF1 & & & -0.403 & 0.006 & & \\
\hline \multirow[t]{4}{*}{ IGFBP-3 } & IGF1 & 0.595 & 0.006 & 0.660 & 0.006 & & \\
\hline & IGF2 & 0.809 & 0.0001 & 0.755 & 0.006 & & \\
\hline & pro-IGF2 & 0.587 & 0.0001 & 0.559 & 0.006 & & \\
\hline & Bioactive IGF1 & & & 0.394 & 0.005 & & \\
\hline \multirow[t]{4}{*}{ Total IGF1 } & Total IGF2 & 0.462 & 0.006 & 0.421 & 0.005 & & \\
\hline & pro-IGF2 & & & 0.487 & 0.005 & & \\
\hline & Bioactive IGF1 & 0.494 & 0.006 & 0.523 & 0.005 & & \\
\hline & IGF1:IGFBP-3 & & & & & 0.854 & 0.006 \\
\hline \multirow[t]{2}{*}{ Total IGF2 } & sIGF2R & 0.488 & 0.005 & & & 0.522 & 0.006 \\
\hline & pro-IGF2 & 0.5 & 0.006 & 0.368 & 0.005 & 0.446 & 0.006 \\
\hline pro-IGF2 & SIGF2R & & & & & 0.460 & 0.006 \\
\hline
\end{tabular}

sIGF2R, soluble IGF2 receptor.

${ }^{\mathrm{a}} \Delta$ Correlations were conducted between the change in value between baseline and week 12 for both variables.

subjects. However, GH was not measured in the current study.

In the current study, the change in IGF1 bioactivity is only reported directly following the weight loss phase. Therefore, what happens during weight maintenance is unknown. A recent study in pre-menopausal women at an increased risk of breast cancer has showed that serum total IGF1 increased following weight loss, but there was no change in free IGF1 (41). Another study by Rasmussen et al. (10) showed that free IGF1 was lower in obese subjects, and that the levels returned to that seen in non-obese subjects following weight loss. However, neither of these studies measured IGF1 bioactivity.

Moderate energy restriction in the current study effectively induced weight loss and lowered total IGF2. A similar result was reported by Espelund et al. (13), who subjected their volunteers to a more severe energy restriction of $800 \mathrm{kcal} /$ day for 8 weeks and showed a similar reduction in total IGF2 concentration. As we also showed that pro-IGF2 decreased in conjunction with decreased IGF2, this suggests that under energy restriction, there is a decreased production of pro-IGF2, rather than an increased conversion of pro-IGF2 to total IGF2. The change in total IGF2 may be regulated by an improvement in insulin sensitivity as the change in IGF2 correlated with a change in HOMA1-IR. To examine this further, it is necessary to investigate gene expression of IGF2 to identify if energy restriction regulates IGF2 at the cell level.

Diet-induced weight loss reduced serum sIGF2R concentrations, irrespective of diet type. This is in agreement with observations following gastric banding, which also lead to reductions in sIGF2R (27). At this stage, the role of sIGF2R in obesity is not clear, but the soluble receptor is able to bind IGF2 and block IGF2induced DNA synthesis in a number of cell lines, thus modulating cell growth (42). Furthermore, the

Table 4 Correlations between insulin-like growth factor (IGF) and various parameters which include body composition, insulin sensitivity and adipokines (only significant correlations have been included).

\begin{tabular}{|c|c|c|c|c|c|c|}
\hline & \multicolumn{2}{|c|}{ Baseline } & \multicolumn{2}{|c|}{12 weeks } & \multicolumn{2}{|c|}{$\Delta^{a}$} \\
\hline & $r$ & $P$ value & $r$ & $P$ value & $r$ & $P$ value \\
\hline $\begin{array}{l}\text { Body weight } \\
\text { IGFBP-1 } \\
\text { IGFBP-2 }\end{array}$ & & & $\begin{array}{l}-0.369 \\
-0.369\end{array}$ & $\begin{array}{l}0.011 \\
0.05\end{array}$ & & \\
\hline $\begin{array}{l}\text { Total abdom } \\
\text { IGFBP-1 } \\
\text { IGFBP-2 }\end{array}$ & & & $\begin{array}{l}-0.417 \\
-0.356\end{array}$ & $\begin{array}{l}0.001 \\
0.02\end{array}$ & & \\
\hline $\begin{array}{l}\text { HOMA1-IR } \\
\text { IGFBP-1 } \\
\text { IGFBP-2 } \\
\text { sIGF2R } \\
\text { Total IGF1 } \\
\text { IGF2 }\end{array}$ & $\begin{array}{r}-0.455 \\
0.338 \\
0.426\end{array}$ & $\begin{array}{l}0.001 \\
0.027 \\
0.001\end{array}$ & $\begin{array}{r}-0.500 \\
-0.555 \\
0.319\end{array}$ & $\begin{array}{l}0.001 \\
0.001 \\
0.045\end{array}$ & $\begin{array}{r}0.341 \\
-0.386 \\
0.414\end{array}$ & $\begin{array}{l}0.027 \\
0.01 \\
0.001\end{array}$ \\
\hline
\end{tabular}

HOMA1-IR, homeostasis model assessment of insulin resistance; sIGF2R, soluble IGF2 receptor.

${ }^{a} \Delta$ Correlations were conducted between the change in value between baseline and week 12 for both variables. 
concentration of sIGF2R at baseline correlated with IGF2 which suggests that they are regulated by similar factors.

Adiponectin increased and leptin decreased following both diets, which is consistent with the reduction in total abdominal fat mass in these subjects. However, it is not clear whether these changes in adipokines directly influence changes in circulating IGF levels following weight loss.

In summary, weight loss induced by moderate energy restriction had the largest influence on total and bioactive IGF1, IGFBP-1, -2 and -3, pro-IGF2 and sIGF2R concentrations, which were independent of type of diet, HP or HC. Although IGF2 levels decreased following weight loss (independent of diet type), the increase in IGF1 concentration and bioactivity might be explained by improvements in insulin sensitivity. To further understand the longer term changes in IGF levels following weight loss, it would be important to examine IGF levels during weight maintenance and/or weight regain in future studies.

\section{Supplementary data}

This is linked to the online version of the paper at http://dx.doi.org/ 10.1530/EJE-10-0062.

\section{Declaration of interest}

The authors declare that there is no conflict of interest that could be perceived as prejudicing the impartiality of the research reported.

\section{Funding}

Meat and Livestock Australia provided financial support for this study. D P B received a travel grant from the Australian Academy of Science which supported this collaborative study.

\section{Author contribution statement}

D P B contributed to the study design, interpretation of data, and the drafting and revision of the manuscript. $\mathrm{M} \mathrm{N}$ designed the study, critically reviewed the manuscript and contributed to interpretation of the data. P M C critically reviewed the manuscript and contributed to interpretation of the data. U E and $\mathrm{N} \mathrm{J} \mathrm{performed}$ the assays and critically reviewed the manuscript; J F and A F critically reviewed the manuscript and contributed to interpretation of the data.

\section{Acknowledgements}

The help of the clinical research unit staff and laboratory staff at CSIRO Food and Nutritional Sciences is gratefully acknowledged in the conduct of the study. We also thank Kylie Lange for statistical advice and the volunteers for participating in the study.

\section{References}

1 Havel PJ. Control of energy homeostasis and insulin action by adipocyte hormones: leptin, acylation stimulating protein, and adiponectin. Current Opinion in Lipidology 200213 51-59.
2 Lu JY, Huang KC, Chang LC, Huang YS, Chi YC, Su TC, Chen CL \& Yang WS. Adiponectin: a biomarker of obesity-induced insulin resistance in adipose tissue and beyond. Journal of Biomedical Science 200815 565-576.

3 Renehan AG, Frystyk J \& Flyvbjerg A. Obesity and cancer risk: the role of the insulin-IGF axis. Trends in Endocrinology and Metabolism $200617328-336$.

4 Yang J, Anzo M \& Cohen P. Control of aging and longevity by IGF-I signaling. Experimental Gerontology 200540 867-872.

5 Frystyk J, Brick DJ, Gerweck AV, Utz AL \& Miller KK. Bioactive insulin-like growth factor-I in obesity. Journal of Clinical Endocrinology and Metabolism 200994 3093-3097.

6 Gregoire Nyomba BL, Johnson M, Berard L \& Murphy LJ. Relationship between serum leptin and the insulin-like growth factor-I system in humans. Metabolism 199948 840-844.

7 Ricart W \& Fernandez-Real JM. No decrease in free IGF-I with increasing insulin in obesity-related insulin resistance. Obesity Research $20019631-636$.

8 Rasmussen MH, Juul A, Kjems LL \& Hilsted J. Effects of short-term caloric restriction on circulating free IGF-I, acid-labile subunit, IGF-binding proteins (IGFBPs)-1-4, and IGFBPs-1-3 protease activity in obese subjects. European Journal of Endocrinology 2006 155 575-581.

9 Gomez JM, Maravall FJ, Gomez N, Navarro MA, Casamitjana R \& Soler J. The IGF-I system component concentrations that decrease with ageing are lower in obesity in relationship to body mass index and body fat. Growth Hormone \& IGF Research 2004 14 91-96.

10 Rasmussen $\mathrm{MH}$, Juul A \& Hilsted J. Effect of weight loss on free insulin-like growth factor-I in obese women with hyposomatotropism. Obesity 200715 879-886.

11 Frystyk J, Vestbo E, Skjaerbaek C, Mogensen CE \& Orskov H. Free insulin-like growth factors in human obesity. Metabolism 199544 37-44.

12 Bang P, Brismar K, Rosenfeld RG \& Hall K. Fasting affects serum insulin-like growth factors (IGFs) and IGF-binding proteins differently in patients with noninsulin-dependent diabetes mellitus versus healthy nonobese and obese subjects. Journal of Clinical Endocrinology and Metabolism $1994 \mathbf{7 8} 960-967$.

13 Espelund U, Bruun JM, Richelsen B, Flyvbjerg A \& Frystyk J. Proand mature IGF-II during diet-induced weight loss in obese subjects. European Journal of Endocrinology 2005153 861-869.

14 Arciero PJ, Gentile CL, Pressman R, Everett M, Ormsbee MJ, Martin J, Santamore J, Gorman L, Fehling PC, Vukovich MD \& Nindl BC. Moderate protein intake improves total and regional body composition and insulin sensitivity in overweight adults. Metabolism $2008 \mathbf{5 7} 757-765$.

15 Grundy SM, Hansen B, Smith SC Jr, Cleeman JI \& Kahn RA. Clinical management of metabolic syndrome: report of the American Heart Association/National Heart, Lung, and Blood Institute/American Diabetes Association conference on scientific issues related to management. Circulation 2004109 551-556.

16 Benassi-Evans B, Clifton PM, Noakes M, Keogh JB \& Fenech M. High protein-high red meat versus high carbohydrate weight loss diets do not differ in effect on genome stability and cell death in lymphocytes of overweight men. Mutagenesis 200924 271-277.

17 O'Callaghan NJ, Clifton PM, Noakes M \& Fenech M. Weight loss in obese men is associated with increased telomere length and decreased abasic sites in rectal mucosa. Rejuvenation Research 200912 169-176.

18 Brinkworth GD, Noakes M, Buckley JD \& Clifton PM. Weight loss improves heart rate recovery in overweight and obese men with features of the metabolic syndrome. American Heart Journal 2006 152 e691-e696.

19 Hodge A, Patterson AJ, Brown WJ, Ireland P \& Giles G. The Anti Cancer Council of Victoria FFQ: relative validity of nutrient intakes compared with weighed food records in young to middle-aged women in a study of iron supplementation. Australian and New Zealand Journal of Public Health 200024 576-583. 
20 Xinying PX, Noakes M \& Keogh J. Can a food frequency questionnaire be used to capture dietary intake data in a 4 week clinical intervention trial? Asia Pacific Journal of Clinical Nutrition 200413 318-323.

21 Matthews DR, Hosker JP, Rudenski AS, Naylor BA, Treacher DF \& Turner RC. Homeostasis model assessment: insulin resistance and beta-cell function from fasting plasma glucose and insulin concentrations in man. Diabetologia $1985 \mathbf{2 8} 412-419$.

22 Frystyk J, Dinesen B \& Orskov H. Non-competitive time-resolved immunofluorometric assays for determination of human insulinlike growth factor I and II. Growth Regulation 1995 5 169-176.

23 Chen JW, Ledet T, Orskov H, Jessen N, Lund S, Whittaker J, De Meyts P, Larsen MB, Christiansen JS \& Frystyk J. A highly sensitive and specific assay for determination of IGF-I bioactivity in human serum. American Journal of Physiology. Endocrinology and Metabolism 2003284 E1149-E1155.

24 Westwood M, Gibson JM, Davies AJ, Young RJ \& White A. The phosphorylation pattern of insulin-like growth factor-binding protein-1 in normal plasma is different from that in amniotic fluid and changes during pregnancy. Journal of Clinical Endocrinology and Metabolism $1994 \mathbf{7 9} 1735-1741$.

25 Krassas GE, Pontikides N, Kaltsas T, Dumas A, Frystyk J, Chen JW \& Flyvbjerg A. Free and total insulin-like growth factor (IGF)-I, -II, and IGF binding protein-1, -2 , and -3 serum levels in patients with active thyroid eye disease. Journal of Clinical Endocrinology and Metabolism 200388 132-135.

26 Franco C, Bengtsson BA \& Johannsson G. The GH/IGF-1 axis in obesity: physiological and pathological aspects. Metabolic Syndrome and Related Disorders 20064 51-56.

27 Jeyaratnaganthan N, Højlund K, Kroustrup JP, Larsen JF, Bjerre M, Levin K, Beck-Nielsen H, Flyvbjerg A \& Frystyk J. Circulating levels of insulin-like growth factor II/mannose 6 phosphate receptor in obesity and type 2 diabetes. Growth Hormone $\mathcal{E}$ IGF Research 2010. DOI:10.1016/j.ghir.2009.12.005.

28 Frystyk J, Tarnow L, Hansen TK, Parving HH \& Flyvbjerg A. Increased serum adiponectin levels in type 1 diabetic patients with microvascular complications. Diabetologia $2005 \mathbf{4 8}$ 1911-1918.

29 Aickin M \& Gensler H. Adjusting for multiple testing when reporting research results: the Bonferroni vs Holm methods. American Journal of Public Health 199686 726-728.

30 Dawson-Hughes B, Harris SS, Rasmussen H, Song L \& Dallal GE. Effect of dietary protein supplements on calcium excretion in healthy older men and women. Journal of Clinical Endocrinology and Metabolism 200489 1169-1173.

31 Larsson SC, Wolk K, Brismar K \& Wolk A. Association of diet with serum insulin-like growth factor I in middle-aged and elderly men. American Journal of Clinical Nutrition 200581 1163-1167.

32 Giovannucci E, Pollak M, Liu Y, Platz EA, Majeed N, Rimm EB \& Willett WC. Nutritional predictors of insulin-like growth factor I and their relationships to cancer in men. Cancer Epidemiology, Biomarkers and Prevention 200312 84-89.
33 Norat T, Dossus L, Rinaldi S, Overvad K, Gronbaek H, Tjonneland A, Olsen A, Clavel-Chapelon F, Boutron-Ruault MC, Boeing H, Lahmann PH, Linseisen J, Nagel G, Trichopoulou A, Trichopoulos D, Kalapothaki V, Sieri S, Palli D, Panico S, Tumino R, Sacerdote C, Bueno-de-Mesquita HB, Peeters PH, van Gils CH, Agudo A, Amiano P, Ardanoz E, Martinez C, Quiros R, Tormo MJ, Bingham S, Key TJ, Allen NE, Ferrari P, Slimani N, Riboli E \& Kaaks R. Diet, serum insulin-like growth factor-I and IGF-binding protein-3 in European women. European Journal of Clinical Nutrition 200761 91-98.

34 Kaklamani VG, Linos A, Kaklamani E, Markaki I, Koumantaki Y \& Mantzoros CS. Dietary fat and carbohydrates are independently associated with circulating insulin-like growth factor 1 and insulin-like growth factor-binding protein 3 concentrations in healthy adults. Journal of Clinical Oncology $1999173291-3298$.

35 Fontana L, Weiss EP, Villareal DT, Klein S \& Holloszy JO. Long-term effects of calorie or protein restriction on serum IGF-1 and IGFBP-3 concentration in humans. Aging Cell 20087 681-687.

36 Kelijman M \& Frohman LA. Enhanced growth hormone (GH) responsiveness to GH-releasing hormone after dietary manipulation in obese and nonobese subjects. Journal of Clinical Endocrinology and Metabolism 198866 489-494.

37 Rasmussen MH, Juul A, Kjems LL, Skakkebaek NE \& Hilsted J. Lack of stimulation of 24-hour growth hormone release by hypocaloric diet in obesity. Journal of Clinical Endocrinology and Metabolism $199580796-801$.

38 Boni-Schnetzler M, Schmid C, Meier PJ \& Froesch ER. Insulin regulates insulin-like growth factor I mRNA in rat hepatocytes. American Journal of Physiology 1991260 E846-E851.

39 Hedman CA, Frystyk J, Lindstrom T, Chen JW, Flyvbjerg A, Orskov H \& Arnqvist HJ. Residual beta-cell function more than glycemic control determines abnormalities of the insulin-like growth factor system in type 1 diabetes. Journal of Clinical Endocrinology and Metabolism 200489 6305-6309.

40 Rasmussen MH, Hvidberg A, Juul A, Main KM, Gotfredsen A, Skakkebaek NE, Hilsted J \& Skakkebae NE. Massive weight loss restores 24-hour growth hormone release profiles and serum insulin-like growth factor-I levels in obese subjects. Journal of Clinical Endocrinology and Metabolism 199580 1407-1415.

41 Harvie M, Renehan AG, Frystyk J, Flyvbjerg A, Mercer T, Malik R, Adams J, Cuzick J \& Howell A. Increase in serum total IGF-I and maintenance of free IGF-I following intentional weight loss in premenopausal women at increased risk of breast cancer. The Open Obesity Journal 2010 In press.

42 Scott CD \& Weiss J. Soluble insulin-like growth factor II/mannose 6-phosphate receptor inhibits DNA synthesis in insulin-like growth factor II sensitive cells. Journal of Cellular Physiology $200018262-68$.

Received 25 February 2010

Accepted 8 March 2010 